Original Article

\title{
IN VITRO STUDY ON PROTEASE AND THROMBOLYTIC ACTIVITY OF AQUEOUS EXTRACT FROM LEUCAS ASPERA (L.) LEAVES
}

\author{
NAGAMANI J. E..$^{*}$, USHA SAH ${ }^{1}$, RAVINDRANATH H. A. ${ }^{2}$
}

1Department of Biochemistry, School of Sciences, Garden City University, Bengaluru 570049, Karnataka, India, ${ }^{2}$ Central Animal Facility, Indian Institute of Science, Bengaluru 570049, Karnataka, India

${ }^{*}$ Email: nagamani_je@gardencity.university

Received: 24 Feb 2021, Revised and Accepted: 10 May 2021

\section{ABSTRACT}

Objective: The current study is an attempt to screen for the in vitro clot lysis and proteolytic activity of aqueous extract of Leucas aspera leaves.

Methods: Thrombolytic activity and protease activity of the crude enzyme obtained by ammonium sulfate precipitation and dialysis were assayed using blood clot and casein as substrates respectively. Native PAGE and gel documentation studies were performed to calculate the molecular weight of the enzyme.

Results: In the study, 40\% salt fractioned crude enzyme sample exhibited significant thrombolytic and caseinolytic activity. Further dosedependent increased activity was observed with the maximum lytic activity of $52.11 \pm 1.04 \%$ at $1 \mathrm{mg} / \mathrm{ml}$ of the sample when compared to the reference drug streptokinase (71.39 $\pm 0.32 \%)$. Also, $68.72 \pm 0.62 \mathrm{U} / \mathrm{hr}$ of caseinolytic activity was observed for $1 \mathrm{mg} / \mathrm{ml}$ of the sample fraction.

Conclusion: The study highlights and validates the efficacy of Leucas aspera leaves extract for thrombolytic and proteolytic actions. Enzyme with an approximate molecular weight, $19.89 \mathrm{KDa}$ could be responsible for the significant lytic activity.

Keywords: Leucas aspera, Thrombolytic activity, Proteolytic activity, Native PAGE

(C) 2021 The Authors. Published by Innovare Academic Sciences Pvt Ltd. This is an open access article under the CC BY license (https://creativecommons.org/licenses/by/4.0/) DOI: https://dx.doi.org/10.22159/ijpps.2021v13i7.41210. Journal homepage: https://innovareacademics.in/journals/index.php/ijpps

\section{INTRODUCTION}

Blood clot (thrombus) developed in the circulatory system due to the failure of homeostasis causes vascular blockage and while recovering leads to serious consequences in atherothrombotic diseases [1-3] Thromboembolic disorders such as myocardial infarction, cerebrovascular thrombosis, pulmonary embolism, and venous thrombolism are life-threatening for human beings [4]. Thrombolytics are used to dissolve the fibrin of blood clots, which are potentially lifethreatening, especially those in the arteries of the heart and lungs. It is also used against the clot formed in shunts during kidney dialysis and multiple pulmonary emboli. Commonly used thrombolytic agents are Alteplase, Anistreplase, Streptokinase, Urokinase, and tissue plasminogen activator (TPA) to dissolve clots [5]

All available thrombolytic agents still have significant shortcomings, including the need for large doses to be maximally effective, limited fibrin specificity. Though streptokinase and urokinase are widely used due to their lower cost, as compared to other thrombolytic drugs, these are dangerous because they might cause serious bleeding complications along with reocclusion and reinfarction [6]. Because of the shortcomings of the available thrombolytic drugs, attempts are underway to develop improved recombinant variants of these drugs [7-9]. Day by day the context, concept, and methods of the use of natural products in the treatment of humans have undergone remarkable changes. Such changes occurred since natural medicine or traditional medicine made a revolutionary come-back with renewed strength and vigor to play a more significant role in the management of human health [10].

Some plants or plant parts showing thrombolytic activity have also been reported. For example, plant extracts of Ageratum conyzoides L Clausena suffruticosa, Leea indica and peel extract of Punica granatum showed a significant percentage of clot lysis compared to reference drug streptokinase [11-13]. Leucas aspera, belonging to the family of Labiatae, is a common aromatic herb. Traditionally, the whole plant is used for analgesic, antipyretic, antirheumatic, anti-inflammatory, and antibacterial treatment. Its anti-inflammatory activity has been shown in animal models through prostaglandin inhibition [14-17]. The current study aims at determining the thrombolytic and proteolytic activities of Leucas aspera leaves extract.

\section{MATERIALS AND METHODS}

\section{Chemicals and reagents}

Streptokinase and trypsin (RM612) were purchased from Sigma Aldrich St Louis, MO, USA. Casein, Bovine Serum Albumin, TEMED and PAGE chemicals from HI-MEDIA, Mumbai, India. All the chemicals and reagents used were of analytical grade. Fresh human blood samples were collected from healthy volunteers after obtaining their consent.

\section{Plant material}

Fresh leaves of Leucas aspera were collected during the year 201718 from Saranda chiria forest, Paschimi Singhbhum district of Jharkhand, India and taxonomically authenticated by Prof. Hari Shankar, Plant taxonomist, Jharkhand Biodiversity Board, Ranchi, India. The sample specimen was submitted to the Botanical survey of India, Kolkata (Herbarium voucher number-86206).

\section{Preparation of extract}

Leucas aspera leaves sample was cleaned, shade dried, pulverized, and stored in an airtight container.

$50 \mathrm{gm}$ of leaf powder was homogenized with distilled water using mortar and pestle. The extract was filtered and centrifuged at 5000 RPM for $15 \mathrm{~min}$. The supernatant was subjected to protein precipitation for $40 \%$ ammonium sulphate fractionation. After ammonium sulphate precipitation, the sample was subjected to centrifugation for $10 \mathrm{~min}$ at $10,000 \mathrm{~g}$. The precipitated pellet was dissolved in $10 \mathrm{mmol}$ phosphate buffer and dialyzed against the same buffer to remove ammonium sulphate. Protein concentration of the fraction was measured at $540 \mathrm{~nm}$ using Biuret reagent.

\section{Caseinolytic activity}

Caseinolytic activity was assayed as per the method of Murata et al. [18]. Briefly, $0.4 \mathrm{ml}$ casein $(2 \%$ in $0.2 \mathrm{M}$ Tris-HCl buffer. $\mathrm{pH} 8.5)$ was 
incubated with different concentrations (250-1000 $\mu \mathrm{g}$ ) of $40 \%$ fraction and trypsin at $37{ }^{\circ} \mathrm{C}$ separately for $2 \mathrm{~h}$. The reaction was stopped by adding $1.5 \mathrm{ml}$ of the $0.44 \mathrm{M}$ TCA and allowed to stand for 30 min followed by centrifugation at $1500 \mathrm{~g}$ for $15 \mathrm{~min}$. An aliquot (1 ml) of the supernatant was mixed with $2.5 \mathrm{ml}$ of the $0.4 \mathrm{M}$ sodium carbonate and $0.5 \mathrm{ml}$ of $\mathrm{FC}$ reagent (1:2) followed by reading absorbance at $660 \mathrm{~nm}$. One unit of enzyme activity was defined as the amount of the enzyme required to increase in absorbance of 0.01 at $660 \mathrm{~nm} / \mathrm{h}$ at $37^{\circ} \mathrm{C}$. Enzyme activity was expressed as $\mathrm{U} / \mathrm{h}$ at $37^{\circ} \mathrm{C}$.

\section{Thrombolytic activity}

In vitro thrombolytic activity in terms of clot lysis was carried out. Venous blood drawn from healthy volunteers was transferred in different pre-weighed sterile microcentrifuge tubes (500 $\mu \mathrm{l} /$ tube) and incubated at $37{ }^{\circ} \mathrm{C}$ for $45 \mathrm{~min}$. After clot formation, serum was completely removed and each tube having clot was again weighed to determine the clot weight (clot weight = weight of clot containing tube-weight of the tube alone). Each micro-centrifuge tube containing the clot was properly labeled and various concentrations of the crude enzyme were added to the tubes (20-100 $\mu \mathrm{g})$. Distilled water and streptokinase were added separately to the tubes containing the clot to serve as a negative control and positive control respectively. All the tubes were then incubated at $37^{\circ} \mathrm{C}$ for $90 \mathrm{~min}$ and observed for clot lysis. Fluid obtained after incubation was removed and tubes were again weighed to observe the difference in weight after clot disruption. The difference obtained in the weight before and after clot lysis was expressed as the percentage of clot lysis.

$$
\text { Percentage of clot lysis (\% of clot lysis) }=\frac{\text { Wt of released clot }}{\text { Wt of total clot }} \times 100
$$

\section{Electrophoresis}

Native PAGE (12\%) was carried out for $40 \%$ dialyzed fraction and the bands were visualized by staining with Coomassie Brilliant Blue R250. Gel imaging and documentation were done using the Bio-Rad Gel Doc EZ system.

\section{Statistical analysis}

The analysis was done using Microsoft excel. All the experiments were conducted in triplicates. One-way ANOVA and post hoc tests were conducted and $\mathrm{P}$ values less than 0.05 were considered as significantly different. Values were represented as mean \pm SEM.

\section{RESULTS AND DISCUSSION}

Proteases constitute one of the most important groups of industrial enzymes, accounting for about $60 \%$ of the total enzyme market. Recent years have envisaged a surge in enzyme market growth due to diverse key factors including cost-effectiveness and productivity. Plant proteases have been implicated in the design and synthesis of therapeutic agents [19]. Herein we report on the potent protease and clot lysis activities of the enzyme from $L$. aspera leaves extract. $40 \%$ dialyzed fraction contained $1.6 \mathrm{mg} / \mathrm{ml}$ of crude protein. Native PAGE under non-reducing conditions revealed a dense single banding for the crude enzyme of $40 \%$ dialysis fraction (DF) from L. aspera (fig. 1a). Proteolytic activity of the crude enzyme from $40 \%$ dialysis fraction was examined using casein as a substrate. DF exhibited potential caseinolytic activity when $2 \%$ of casein was used as a substrate. The activity was progressively increased with an increase in the concentration of the enzyme fraction. The protein concentration ranging from $250 \mu \mathrm{g} / \mathrm{ml}$ to $1000 \mu \mathrm{g} / \mathrm{ml}$ exhibited a mean activity of $19.63 \pm 0.19 \mathrm{U} / \mathrm{hr}$ to $68.72 \pm 0.62 \mathrm{U} / \mathrm{hr}$ respectively (fig. 2). Trypsin and distilled water (DW) used as a positive and negative control showed activities of $84.2 \pm 1.18 \mathrm{U} / \mathrm{hr}$ and $2.56 \pm 0.09 \mathrm{U} / \mathrm{hr}$ respectively (table 1 ). Furthermore, purification and characterization of protease $(s)$ are in progress to categorize the protease for two varied classes viz., cysteine proteases or serine proteases.

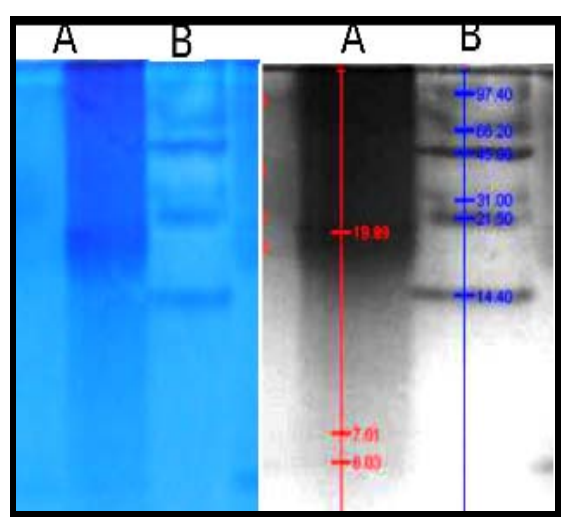

Fig. 1: Native PAGE of 40\% DF A-sample, B-marker protein

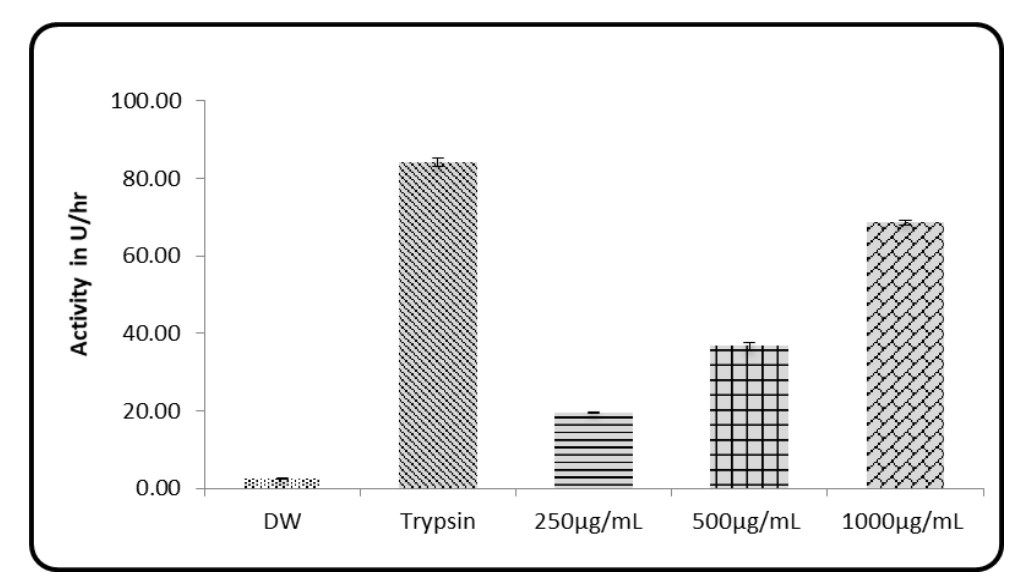

Fig. 2: Protease activity of $40 \%$ dialysed fraction, values are mean $\pm S E M, n=3$, significant at ap $<0.05$

\section{Thrombolytic activity}

Fibrinolytic enzymes dissolve fibrin, the main component of blood clots. Accumulation of fibrin in the blood vessels results in thrombosis, leading to myocardial infarction, and other heart diseases [20]. Several anticoagulants, anti-platelet, and thrombolytic medications are used for the treatment of thrombotic disorders. Anticoagulants and anti-platelet agents prevent the formation of blood clots but do not dissolve existing clots, whereas thrombolytic agents can dissolve a clot but emboli can form even after successful treatment. Thus, none of them provide a permanent and complete solution [21]. Thrombolytic drugs dissolve blood clots by activating plasminogen, which forms a cleaved product called plasmin. Plasmin is a proteolytic enzyme that is capable of breaking cross-links between fibrin molecules, thereby dissolving the blood clots.

The addition of the DF with enzyme aliquots varying from 250 to $1000 \mu \mathrm{g} / \mathrm{ml}$ to the preformed blood clots and subsequent incubation for $90 \mathrm{~min}$ at $37^{\circ} \mathrm{C}$ demonstrated a dose-dependent response with maximum lysis of $52.11 \pm 1.04 \%$ (table 1 ). $100 \mu$ l of streptokinase 
taken as a positive control ( $35000 \mathrm{IU}$ ) showed $71 \%$ clot lysis activity and distilled water used as negative control exhibited 6.04 $\%$ of lysis action (fig. 3). Gel documentation study for the $40 \%$ DF resolved under nonreducing native PAGE divulged the approximate molecular weight of the crude enzyme as $19.89 \mathrm{KDa}$ (fig. 1b) which is attributed to the lysis of clot releasing the fibrin monomers.

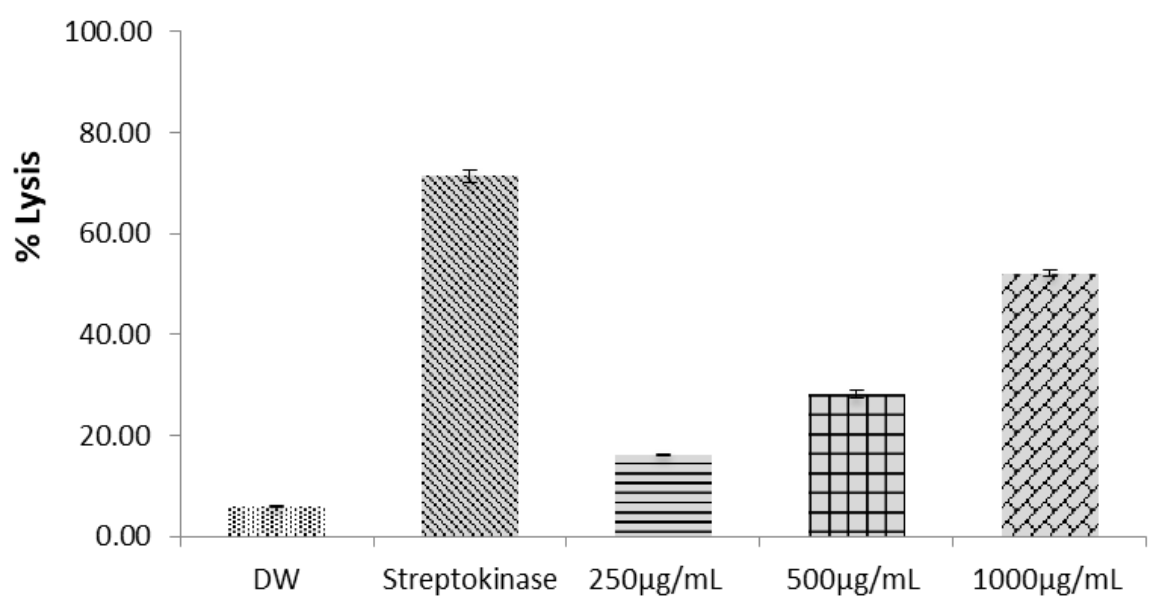

Fig. 3: Clot lysis activity of crude enzyme from dialyzed fraction, values are mean \pm SEM, $n=3$, significant at ap $<0.05$

Table 1: Protease and thrombolytic activities of crude enzyme

\begin{tabular}{lll}
\hline Sample & Protease activity (U/h) & Thrombolytic activity (\% lysis) \\
\hline DW & $2.56 \pm 0.09$ & $6.04 \pm 0.21$ \\
Trypsin & $84.20 \pm 1.18$ & - \\
Streptokinase & - & $71.39 \pm 0.32$ \\
DF $(250 \mu \mathrm{g} / \mathrm{ml})$ & $19.63 \pm 0.19 \mathrm{a}$ & $16.18 \pm 0.26 \mathrm{a}$ \\
DF $(500 \mu \mathrm{g} / \mathrm{ml})$ & $36.79 \pm 0.86 \mathrm{a}$ & $28.17 \pm 0.59 \mathrm{a}$ \\
DF $(1000 \mu \mathrm{g} / \mathrm{ml})$ & $68.72 \pm 0.62 \mathrm{a}$ & $52.11 \pm 1.04 \mathrm{a}$ \\
\hline
\end{tabular}

DF-Dialyzed fraction from $40 \%$ salt precipitation, values are means \pm SEM, $n=3$, significant at ap $<0.05$

\section{CONCLUSION}

In the context of the above result and discussion, it can be concluded that the enzyme extract of $L$. aspera leaves possesses significant protease and thrombolytic activity compared to the standard enzyme trypsin and streptokinase respectively. However, further studies are in progress to purify and characterize the enzyme from the crude dialyzed sample. Also cytotoxic studies have to be taken up further to explore the medical and pharmaceutical potentiality of the plant.

\section{ACKNOWLEDGMENT}

I record a deep sense of indebtedness and gratitude to Dr. Joseph VG, Chancellor, Garden City University for providing the seed money to carry out this research project.

\section{FUNDING}

Nil

\section{AUTHORS CONTRIBUTIONS}

All authors contributed to the study's conception and design. Nagamani JE and Usha sah performed the experiment and analysis. The first draft of the manuscript was written by Nagamani JE and the critical revision of the manuscript was done by Ravindranath $\mathrm{H} \mathrm{A}$. All authors read and approved the final manuscript.

\section{CONFLICT OF INTERESTS}

This statement is to declare that all authors involved in this manuscript have no conflict of interest.

\section{REFERENCES}

1. Kumar S, Joseph L, George M, Sharma A. A review on the anticoagulant/antithrombotic activity of natural plants used in traditional medicine. Int J Pharm Sci Rev Res 2011;8:70-4.
2. Irfan Newaz Khan, Razibul Habib, Mominur Rahman. Thrombolytic potential of Ocimum sanctum L., Curcuma longa L., Azadirachta indica L. and Anacardium occidentale L. J Basic Clin Pharm 2011;2:125-7.

3. Collen D. Coronary thrombolysis: streptokinase or recombinant tissue-type plasminogen activator. Ann Intern Med 1990;112:529-38.

4. Sweta Prasad, Rajpal S Kashyap, Jayant Y Deopujari. Development of an in vitro model to study clot lysis activity of the thrombolytic drug. Thrombosis J 2006;4:1-14.

5. Nicolini FA, Nichols WW, Mehta JL, Saldeen TG. Sustained reflow in dogs with coronary thrombosis with $\mathrm{K} 2 \mathrm{P}$, a novel mutant of tissue plasminogen activator. J Am Coll Cardiol 1992;20:228-35.

6. Adams DS, Griffin LA, Nachajko WR, Reddy VB, Wei CM. A synthetic DNA encoding a modified human urokinase resistant to inhibition by the serum plasminogen activator inhibitor. J Biol Chem 1991;266:8476-82.

7. Lijnen HR, Vanhoef B, DeCock F, Okada K. On the mechanism of fibrin-specific plasminogen activation by staphylokinase. J Biol Chem 1991;266:11826-32.

8. Gesler WM. Therapeutic landscapes: medical issues in light of the new cultural geography. Soc Sci Med 1992;34:735-46.

9. Yamamoto J, Yamada K, Naemura A, Yamashita T, Arai R. Testing various herbs for antithrombotic effect. Nutrition 2005;21:580-7.

10. Prasad S, Kashyap RS, Deopujari JY, Purohit HJ, Taori GM, Daginawala HF. Effect of Fagonia Arabica (Dhamasa) on in vitro thrombolysis. BMC Complementary Altern Med 2007;7:36:1-6.

11. Ai Lan Chew, Jeyanthi James Antony Jessica, Sreenivasan Sasidharan. Antioxidant and antibacterial activity of different parts of Leucas aspera. Asian Pacific J Trop Biomed 2012;2:176-80.

12. Goudgaon NM, Basavaraj NR, Vijayalaxmi A. Antiinflammatory activity of different fractions of Leucas aspera. Indian J Pharmacol 2003;35:397-8. 
13. Sampath R, Renuka Saravanan, Brindha Pemiah, Sivakumar Ramalingam. Thrombolytic activity of Punica granatum fruit and peel extract. Asian J Pharm Clin Res 2016;9:268-71.

14. Srinivas K, Rao MEB, Rao SS. Anti-inflammatory activity of Heliotropium indicum linn and Leucas aspera spreng in albino rats. Indian J Pharmacol 2000;32:37-8.

15. Sadhu SK, Okuyama E, Fujimoto H, Ishibashi M. Separation of Leucas aspera, a medicinal plant of Bangladesh, guided by prostaglandin inhibitory and antioxidant activities. Chem Pharm Bull 2003;51:595-8.

16. Sadhu SK, Okuyama E, Fujimoto H, Ishibashi M. Diterpenes from Leucas aspera inhibiting prostaglandin-induced contractions. J Nat Prod 2006;69:988-94.

17. Chew AL, Jessica JJ, Sasidharan S. Antioxidant and antibacterial activity of different parts of Leucas aspera. Asian Pac J Trop Biomed 2012;2:176-80.
18. Murata J, Satake M, Suzuki T. Studies on snake venom XII distribution of proteinase activities among Japanese and formosan snake venoms. J Biochem 1963;53:431-43.

19. Neurath H. The diversity of proteolytic enzymes. A Practical Approach. Oxford, UK: IRL Press; 1990. p. 1-12.

20. Madhusudan Debnath, Susmita Saha, Samir Kumar Sil. First report on the fibrinolytic and thrombolytic activity of Eutyphoeus gammiei an earthworm species collected from tripura, northeast India. Asian J Pharm Clin Res 2018;11:20236-40.

21. Kunwar Awaneesh Singh, Manasa K Nayak, Medicherla V Jagannadham, Debabrata Dash. Thrombolytic along with the anti-platelet activity of crinumin, a protein constituent of Crinum asiaticum. Blood Cells Mol Diseases 2011; 47:129-32. 